\title{
The ideal kindergarten: Views of undergraduate students studying at the faculty of Early Childhood Education of Aristotle University of Thessaloniki
}

\author{
Konstantina Vasilopoulou \\ Kindergarten Teacher, Greece \\ Email: vasilopkon@gmail.com \\ Sofia Nalbantoglou \\ Kindergarten teacher, MA in Pedagogics, Greece \\ Email: snalbantoglou@gmail.com \\ Argyris Kyridis (Corresponding author) \\ Professor, Aristotle University of Thessaloniki, Greece \\ Email: akiridis@ nured.auth.gr \\ Zoe Konstantinidou \\ Kindergarten teacher, Ma in Pedagogics, Greece \\ Email: zoekzoe@hotmail.com
}

Received: July 28, 2016 Accepted: September 14, 2016 Published: October 07, 2016 doi:10.5296/ijld.v6i3.9792 URL: http://dx.doi.org/10.5296/ ijld.v6i3. 9792

\begin{abstract}
Preschool age is one of the most important periods in man's life, in which children grow rapidly while the environment provides proper stimulus so that they are fully developed and can go over to the next educational stages smoothly. A total of factors affects this progress. These factors are related to the program of kindergarten, the practices that are applied, the surrounding area, the relations between the kindergarten teacher and the broader social
\end{abstract}


context, moreover the kindergarten teachers themselves are responsible for such an important function. The purpose of this research is to expand the undergraduate student's views of the University of Early Childhood Education concerning the features of an ideal kindergarten that favors children's development and offers a pleasant and creative stay.

Keywords: Ideal, Kindergarten, Preschool education, Early childhood education, Views, Undergraduate students.

\section{Conceptual Orientation}

\subsection{Students Approaches About Kindergarten From $18^{\text {th }}$ To $20^{\text {th }}$ Century}

Before the $17^{\text {th }}$ century, there was no differentiation between a child and an adult. Children didn't receive special education, their needs weren't acknowledged either. They were the miniature of adults contributing to family's works.

In $17^{\text {th }}$ century, "childhood" is defined and it is acknowledged that a child needs education and protection. A child remains at home environment until the age of 4 and then ages to kindergarten. So it is obvious that the place which hosts children at this critical age is not only a place to stay, but also a place that contributes significantly to their character formation and affects their incorporation to society. From the $18^{\text {th }}$ century, as society develops, researcher's views are expressed that study the philosophy of education, in order to present the features of an ideal school.

\subsection{The Role Of The Kindergarten Teacher}

The teaching-learning situation in Montessori's philosophy is highly individualized by virtue of the fact that children are encouraged to select their own activities while the teacher, called "directress", observes the children and assists them when they truly need help (Miezitis, 1971:42). She argued that "the child is a personality separate from the adult" (Bruce, 2012). Very little didactic group teaching occurs expect for regular demonstrations on the use of the teaching materials to small groups of children (Miezitis, 1971:42). The emphasis is more on the individual child, whereas for Froebel the child is respected as an individual, but relationships with other children and with adults are at the heart of the learning community (Bruce, 2012).

Dewey argued that teachers and children decide together what experience is meaningful to each individual student's current learning needs and later development (Tzuo, 2007). He positioned the teacher as a researcher and co-constructor of learning in partnership with children, within social and community contexts (Garrison, 1996 in Lindsay, 2015: 448).

Early childhood classrooms, which adopt a Piagetian approach, give children the greatest degree of freedom. Teachers set up a rich environment for children to explore by themselves. Teachers are observers (Tzuo, 2007:35). On the other hand, the classroom applying Vygotsky's theory seeks to find a balance between teacher-directed and child initiated activities. Teachers assist children and give them challenges in order that children may attain 
the top level within their zone of proximal development (Tzuo, 2007:35).

The Reggio Emilia's view emphasizes the cooperative role of the teacher; children construct knowledge and make meaning of the world together with her (Dahlberg, Moss and Pence 2007 in Dayan \&Ziv, 2012: 281). The role of the teacher as partner and co-learner is most clearly demonstrated as both child and teacher engage in collaborative learning during the process of working through a project. (Hewett, 2001:97). The teacher does not control nor dominate the child or her learning, but rather, demonstrates respect for the child's rights through mutual participation and joint action (Hewett, 2001:97).

\subsection{Space in Kindergarten}

Children's interactions with their physical environments are identified as an important feature of early childhood pedagogy (Featherstone, 2011 in Murray, 2015:3).As regard Froebel, the kindergarten would have a pleasant physical environment, recommended the use of an adjoining garden or at least a brightly painted, sunny room filled with plants, animals, and pictures (Spodek, 1981).

Dewey extensively discussed the importance of aesthetic learning environments as a human right (Dewey, 1939 in Lindsay, 2015:448). Vygotsky (1978 in Murray, 2015:3) recognized that the 'more knowledgeable other' may allude to physical environment. This idea has been well developed in the Italian Reggio Emilia nurseries where the environment is itself regarded as an 'educator' (Gandini, 1998:177 in Murray, 2015:3).

As referred in "The Reggio Emilia Approach to Early Years Education” (2006), in Reggio Emilia the space must be conducive to research and autonomous discovery, both for individual children and for groups of children working together. An enormous amount of attention and effort goes into the design of furniture and organization of space and materials to maximize the ease of use by the children. Art materials in both the central and mini ateliers are in see-through containers so that children can easily find things on their own. Schools are not painted in the bright primary colors that many adults misconceive to be favored by children. Instead there is a pervasive feeling of light and space brought about by the use of light or white walls and the way in which children's artwork painted on transparent sheets creates interesting layering and diffused light, and the way in which movable walls and wall-size windows allow the interior to integrate with the outside environment.

\subsection{Activities in Kindergarten}

With the impact of the Romantic movement in the 18th century, play came to the fore and was valued. Rousseau believed that play was a child's right. He believed that children aged 0-5 should learn only through play and he rejected the idea that play was essentially doing nothing. Play liberated children. Rousseau's philosophy stressed the importance of play as an instrument for the development of the senses, the exercise of judgment through sensory experience and contact with things.

Education to Froebel had to be based on the interests and spontaneous activities of the child (Sniegoski, 1994:5).Each new interest, activity, or learning grew out of an interest or activity 
already there, whereas the child moved from one stage to the next gradually (Sniegoski, 1994).

Froebel saw play as the highest expression of human development and underlined that play was the free expression of the child's soul (Nordtomme, 2012:318). He established that play was the appropriate justification for early childhood education (Ransbury, 1982 in Saracho, 1991:45), as it gives joy, freedom, contentment, inner and outer rest, peace with, the world (Sniegoski, 1994). Also, Froebel believed that all areas of development could be promoted through play: physical development through callisthenic exercises, social development through children playing and working things out together, sense development through exploring and manipulating playthings, and intellectual development through imitative or inventive use of the Froebel gifts and occupations.

Montessori believed that the child is endowed with epistemic and competence motives that can be elicited by the mere presence of appropriate activities. Attention and learning occur from the child's natural interest in objects with which child can interact in a constructive way (Miezitis, 1971:42). Maria Montessori postulated that play is the work of the child. Children would be best served spending their play time learning or imagining. Montessori's play is sensory, using a hands-on approach to everyday tools like sand tables. The child sets her own pace, and the teacher is collaborative in helping the child play to learn. However, she did not believe in play or toys. Children in her kindergartens experienced real household tasks.

Dewey called for educational activities that would support continuity in children's growth and would be connected to their everyday lives. In Aesthetics Early Childhood education, children's music teaching and learning, children's visual arts and children's pretend play are three significant activities in early childhood education; these three activities yield unique experiences that promote learning, especially for the very young children in early childhood educations or early childhood education (Ko\& Chou, 2014:40).

John Dewey valued play as preparation. Play is a subconscious activity that helps an individual develop both mentally and socially. Through games children learn about the work and play of the grown-up world (Dewey and Dewey, 1962, p. 79 in Henniger, 1991). As children become adults, they no longer "play" but seek amusement from their occupation. This childhood activity of play prepares them to become healthy working adults.

Cognitive theorists, as Piaget and Vygotsky, viewed play in terms of more general psychological development. The developmental theory of Jean Piaget (Cowan, 1978 in Henniger, 1991:65) suggests that kindergarten children are in the preoperational stage of development and learn a great deal intellectually through the physical manipulation of materials in their environment. By playing with blocks, for example, the child gains understandings of concepts such as shape, size, and number. These basic concepts become the building blocks for more complex understandings that will follow in later mathematics and science activities (Henniger, 1991:65). The child at this stage needs a broad base of concrete, real-world experiences before dealing with the more academic activities of the elementary school years (Henniger, 1991:65). 
Lev Vygotsky suggested that children will use play as a means to grow socially. In play, children encounter others and learn to interact using language and role-play. Vygotsky (1967 in (Henniger, 1991:66) saw the imaginary situation in play as an important means for developing abstract thought. As the child becomes more comfortable and capable of mentally manipulating symbols in dramatic play, he or she is better prepared to deal with the arbitrary symbols necessary for abstract thought (Henniger, 1991:66).

As referred in "The Reggio Emilia Approach to Early Years Education" (2006), one of the most interesting elements within the Reggio Approach is the central importance given to the expressive arts as a vehicle for learning. Children are also encouraged to participate in a variety of expressive activities such as sculpture, dramatic play, shadow play, puppetry, painting, dancing, music, ceramics, construction and writing.

\subsection{Relations to the Wider Social Environment In Kindergarten}

Froebel saw the family as the most important first educator in the child's life (Bruce, 2012). For the first years of life, Froebel pointed out; children were wholly dependent upon their mother and other members of their immediate family (Sniegoski, 1994:7). Joachim Liebschner (1985:35 in Bruce, 2012) points out that Froebel believed women were important not only in their role as parents but were capable of teaching children too. This was a revolutionary idea at that time! The school was seen as community, where home and school came together. Parents were seen as part of the community (Bruce, 2012). Thus, he called for the creation of a new institution, halfway between the home and the school--the kindergarten or child garden.18 (Sniegoski, 1994:8).

According to Dewey, the child's life in the home and the community was to be the basis for school activities rather than a set of abstract ideals symbolized in manipulative materials (Weber, 1969 in Spodek, 1981:9). For Piaget, the importance of the social context is that it provides children with a means of testing the knowledge they had constructed (Wadsworth, 1995 in Tzuo, 2007:5). Whereas, for Vygotsky, the social context is both the source and the cultural repository of the learning (Berk\&Winsler, 1995 in Tzuo, 2007:35).

Reggio educators in "The Reggio Emilia Approach to Early Years Education" (2006),describe their approach to learning and teaching as 'pedagogy of relationships' as it is founded on the conviction that we learn through making connections between things, concepts and experiences, and that we do so by interacting with other people and with our surrounding environment. This is evident in the key role given to participation at every level: both within school (between children and between children and adults) and also outwith the school (between families and school and between the greater community and school).

\subsection{Curriculum in Kindergarten}

Notions associated with child-centered education where "nature requires children to be children first" are believed to have initiated from Rousseau's theories on education (Platz and Arellano 2011, p. 56 in Moore et al., 2014:12). Oelkers (2002,p.683in Moore et al., 2014:12-13) in his study of Rousseau and the image of 'modern education', claims that Rousseau "took for granted that the self-development of the child is driven by immediate 
interests, i.e., not by instruction or by formal education", and continues this line of Rousseau's thinking by stating, "If educators let the child always be himself, attending to only what touches him immediately, then and only then will they find the child learning, capable of perceiving, memorizing, and even reasoning”.

Education to Froebel consisted of self-activity, which implied that the learner essentially would educate himself (Sniegoski, 1994:5). The major vehicles of Froebel's curriculum were the gifts, sets of manipulative materials to be used in prescribed ways demonstrated by the kindergarten teacher (e.g., balls, wooden blocks and other materials), and the occupations, a series of craft activities (e.g. paper weaving, paper folding and cutting, and many of the arts-and-crafts activities presently used) (Spodek, 1981). Also songs, games, movement activities, stories, poetry, nature study and gardening rounded out the curriculum (Spodek, 1981).

Maria Montessori developed a very different curriculum for early childhood education (Saracho, 1991:45). She viewed preschool as the time when children develop the social and intellectual growth to become confident and responsible participants in a democratic society (Flynn, 1991:117). Montessori shared many elements of playful learning, including overall structure, the use of small objects for learning, individualized lessons, free choice, peer involvement, fun, and lack of extrinsic rewards (Lillard, 2013:179). Some people do not think Maria Montessori's idea of education is really child-centered, because of the limitations of the didactic apparatus (McMullen, 2003, personal communication in Tzuo, 2007:35).

In Dewey's Progressive Theory the curriculum is child-centered and is rooted in the ideas of continuity and interaction in a social context. Teachers and children decide together what experience is meaningful to each individual student's current learning needs and later development (Tzuo, 2007). Early childhood educators credit Dewey with concepts such as learning through play-based, hands-on activity and project- based approaches to curriculum provision (Lindsay, 2015:448).

The Italian Reggio Emilia approach to early years education, highly regarded for its child-focused pedagogy, employs many of John Dewey's ideas about democracy, education and aesthetics (Lindsay, 2015:447). Within the Reggio Emilia schools there are no planned curriculums or standards indicating what is to be learned (Malaguzzi, 1993b; Rinaldi, 1993 in Hewett, 2001:98), as "these would push our schools towards teaching without learning" (Malaguzzi, 1993, p. 8 in Hewett, 2001:98). Rather, it is up to the children, in collaboration with teachers and one another, to determine the course of their investigations and learning (Malaguzzi, 1993b in Hewett, 2001:98).

\subsection{Children as an entity in Kindergarten}

Rousseau constructs the child as innocent. Rousseau's projection of childhood innocence paved the way for an image of the innocent child needing protection, and a tendency for adults to feel the need to "shelter children from the corrupt surrounding world ... by constructing a form of environment in which the young child will be offered protection, continuity and security" (Dahlberg et al. 1999, p. 45 in Moore et al., 2014:12). Early 
childhood settings have been perceived as providing this protective role, especially in relation to environmental education which has been viewed as a potentially overwhelming topic for the developmental capacity of young children (see for example Duhn2012in Moore et al., 2014:12).

Froebel constructs the child as having rights. A child possesses a "divine essence" in need of only cultivation and protection rather than interference. Dewey's value for children as active agents in their social construction of knowledge (Griebling 2011 in Lindsay, 2015:448) saw him advocate for curricula based on children's interests (Eisner 2002 in Lindsay, 2015:448).

Piaget's (1973 p. 9 in Hewett, 2001:96) reference to children's "investigation" suggests the role of the child as that of a researcher. Also, Piaget constructs the child as an active constructor of knowledge. According to Piaget (1973 p. 9 in Hewett, 2001:96), "A student who achieves a certain knowledge through free investigation and spontaneous effort will later be able to retain it".

Within the Reggio Emilia Approach, the fundamental belief on which the image of the child is constructed is that of the child having rights rather than simply needs (Malaguzzi, 1993a; 1993b; Rinaldi, 1993 in Hewett, 2001:95). According to Loris Malaguzzi (1993b p. 51 in Hewett, 2001:96), "If the children had legitimate rights, then they also should have opportunities to develop their intelligence and to be made ready for the success that would not, and should not, escape them". Influenced by this belief, the child is beheld as beautiful, powerful, competent, creative, curious, and full of potential and ambitious desires (Malaguzzi, 1994; Rinaldi, 1993 in Hewett, 2001:96). Her nature, thoughts, and work are taken seriously and respected; therefore, the act of truly listening to the child is emphasized (Hewett, 2001:96).

\section{Methodology}

\subsection{Research Aim}

The main purpose of this research is to examine the undergraduate students' beliefs regarding the ideal image of Kindergarten. When we use the word "ideal", we subsequently must consider the distinction between the ideal and the typical. In the current survey, students' perceptions are examined in correlation with certain independent variables, such as the students' undergraduate level and family background, their age, their occupation, their residence, their political ideology and the degree of their political participation. These correlations provide the opportunity to create certain patterns of ideals and beliefs, since it is becoming apparent that the students' attitudes towards the ideal Kindergarten is thoroughly influenced by factors that are not necessarily and exclusively linked to the educational environment of the university. Moreover, the students' responses are examined in the light of certain sub-categories, in order to create a more systematic and consistent methodological framework.

\subsection{Research Method}

A written questionnaire was chosen as a research method and data collection instrument. 


\section{Macrothink}

Some of the advantages of its use, distinguishing it from other research tools, are the collection of numerous observations and information in a very short time, the effective study of problems which would require vast and long-term observations and its direct indexing (Vamvoukas, 2002). Also, the preservation of anonymity can greatly increase the responsiveness and willingness to participate (Oppenheim, 1992:102). The validity and reliability of questionnaires were ensured via questions- variables that correspond to the theoretical frame of research.

\subsection{Sample}

Table 1: Demographic and social characteristics of the sample

\begin{tabular}{|c|c|c|c|c|c|}
\hline $\begin{array}{l}\text { Undergraduate } \\
\text { level }\end{array}$ & $\mathbf{N}$ & \multicolumn{4}{|l|}{$\%$} \\
\hline $10-20$ & 40 & \multicolumn{4}{|l|}{50} \\
\hline $30-4 o$ & 40 & \multicolumn{4}{|l|}{50} \\
\hline $\begin{array}{l}\text { Father's } \\
\text { occupation }\end{array}$ & $\mathbf{N}$ & $\%$ & $\begin{array}{l}\text { Mother's } \\
\text { occupation }\end{array}$ & $\mathbf{N}$ & $\%$ \\
\hline $\begin{array}{l}\text { Freelancer- } \\
\text { Scientist }\end{array}$ & 12 & 15,2 & $\begin{array}{l}\text { Freelancer- } \\
\text { Scientist }\end{array}$ & 5 & 6,3 \\
\hline Public official & 24 & 30,4 & Public official & 20 & 25,3 \\
\hline $\begin{array}{l}\text { Private } \\
\text { employee }\end{array}$ & 18 & 22,8 & $\begin{array}{l}\text { Private } \\
\text { employee }\end{array}$ & 19 & 24,1 \\
\hline $\begin{array}{l}\text { Freelancer- } \\
\text { Technician }\end{array}$ & 12 & 15,2 & $\begin{array}{l}\text { Freelancer- } \\
\text { Technician }\end{array}$ & 3 & 3,8 \\
\hline Merchant & 7 & 8,9 & Merchant & 2 & 2,5 \\
\hline Worker & 1 & 1,3 & Worker & 3 & 3,8 \\
\hline Farmer & 5 & 6,3 & Farmer & 3 & 3,8 \\
\hline & & & Household & 24 & 30,4 \\
\hline $\begin{array}{l}\text { Father's } \\
\text { education }\end{array}$ & $\mathbf{N}$ & $\%$ & $\begin{array}{l}\text { Mother's } \\
\text { education }\end{array}$ & $\mathbf{N}$ & $\%$ \\
\hline
\end{tabular}




\begin{tabular}{|c|c|c|c|c|c|}
\hline Illiterate & - & - & Illiterate & - & - \\
\hline Primary school & 6 & 7,7 & $\begin{array}{l}\text { Primary } \\
\text { school }\end{array}$ & 14 & 17,5 \\
\hline $\begin{array}{l}\text { Secondary } \\
\text { school }\end{array}$ & 36 & 46,2 & $\begin{array}{l}\text { Secondary } \\
\text { school }\end{array}$ & 35 & 43,8 \\
\hline $\begin{array}{l}\text { Technological } \\
\text { Institute } \\
\text { Graduate }\end{array}$ & 21 & 26,9 & $\begin{array}{l}\text { Technological } \\
\text { Institute } \\
\text { Graduate }\end{array}$ & 15 & 18,8 \\
\hline $\begin{array}{l}\text { University } \\
\text { Graduate }\end{array}$ & 14 & 17,9 & $\begin{array}{l}\text { University } \\
\text { Graduate }\end{array}$ & 13 & 16,3 \\
\hline Master degree & 1 & 1,3 & Master degree & 3 & 3,8 \\
\hline Age & $\mathbf{N}$ & $\%$ & Occupation & $\mathbf{N}$ & $\%$ \\
\hline 18-22 years old & 67 & 83,8 & Yes & 16 & 20 \\
\hline $\begin{array}{l}\text { Over } 24 \text { years } \\
\text { old }\end{array}$ & 13 & 16,3 & No & 64 & 80 \\
\hline Residence & $\mathbf{N}$ & $\%$ & $\begin{array}{l}\text { Political } \\
\text { ideology }\end{array}$ & $\mathbf{N}$ & $\%$ \\
\hline $\begin{array}{l}\text { Athens- } \\
\text { Thessaloniki }\end{array}$ & 493 & 63,8 & $\begin{array}{l}\text { Extreme } \\
\text { right-wing }\end{array}$ & - & - \\
\hline Urban area & 115 & 14,9 & Right-wing & 95 & 13,4 \\
\hline Town & 131 & 16,9 & Center & 283 & 40,0 \\
\hline Rural area & 34 & 4,4 & Left-wing & 254 & 35,9 \\
\hline $\begin{array}{l}\text { Degree of } \\
\text { political } \\
\text { participation }\end{array}$ & $\mathbf{N}$ & $\%$ & $\begin{array}{l}\text { Extreme } \\
\text { left-wing }\end{array}$ & 17 & 2,4 \\
\hline None & 116 & 15,0 & Anarchist & 58 & 8,2 \\
\hline
\end{tabular}




\begin{tabular}{|l|l|l|l|l|l|}
\hline A little & 427 & 55,2 & & & \\
\hline Indifferent & 39 & 5,0 & & & \\
\hline Adequate & 132 & 17,1 & & & \\
\hline Extremely & 59 & 7,6 & & & \\
\hline
\end{tabular}

Demographic and social characteristics of undergraduate students

\subsection{Content Analysis}

B. Berelson (1971) considers that content analysis is offered for the study of views or perceptions of individual or team of individuals He also notes that it is "a research technique into the objective, systematic and quantitative description of obvious content of communication, written or oral, with final objective the interpretation". De Sola Pool (1959) gave a different dimension in content analysis by noting that it is ideal for the study of meaning and semiotic relations that are contained in written or oral reason. Many years later M. Palmquist used content analysis in written texts of students or teachers (Palmquist, 1990; Weber, 1990). Content analysis focuses on the obvious content and tents to suppose that the later represents a unique constant attention. However, French literature gave a different dimension in the particular method renewing both the technique and possibilities of its use (Bardin, 1977; Moscovici, 1970; Mucchieli, 1988; Veron, 1981; Grawitz, 1981). Finally, we should note that content analysis can also be applied to figurative material, which includes reason as well (Giroux, 1994).

Content analysis as a research tool presents the following advantages (Curley, 1990 in Asher):

- Enables combination of quantitative and qualitative data

- Enables detection and recording of concrete forms of social interaction via discourse analysis

- Enables recording of historical and cultural elements

- Is ideal for recording and analyzing social ideologies

- Enables exploration of significances and the way social subjects conceive it 


\section{Data Analysis}

Table 2: Means table regarding the ideal Kindergarten

\begin{tabular}{|c|c|c|}
\hline & $\mathbf{N}$ & $\%$ \\
\hline $\begin{array}{l}\text { 1. Kindergarten } \\
\text { teacher }\end{array}$ & 129 & 16,7 \\
\hline 1.1 Training & 19 & 2,5 \\
\hline 1.2 Personality elements & 21 & 2,7 \\
\hline $\begin{array}{l}\text { 1.3 Behavior during the } \\
\text { educational process }\end{array}$ & 44 & 5,7 \\
\hline 1.4 Teaching methods & 45 & 5,8 \\
\hline 2.Space & 256 & 33,1 \\
\hline 2.1 Internal & 214 & 27,7 \\
\hline 2.1.1 Equipment & 64 & 8.3 \\
\hline 2.1.2 Decoration & 35 & 4,5 \\
\hline 2.1.3 Functionality & 89 & 11,5 \\
\hline 2.1.4 Helping spaces & 26 & 3,4 \\
\hline 2.2 External & 42 & 5,4 \\
\hline 3. Staff & 32 & 4,1 \\
\hline 4. Activities & 17 & 2,2 \\
\hline 4.1 Indoor & 5 & 0,6 \\
\hline 4.2 Outdoor & 12 & 1,6 \\
\hline 5. Functional principles & 32 & 4,1 \\
\hline 6. Relations to the wider & 43 & 5,6 \\
\hline
\end{tabular}




\begin{tabular}{|l|l|l|}
\hline social environment & (2) & \\
\hline $\begin{array}{l}\text { 6.1 Between kindergarten } \\
\text { teacher \& parents }\end{array}$ & 33 & 4,3 \\
\hline $\begin{array}{l}\text { 6.2 Between kindergarten } \\
\text { teacher \& community }\end{array}$ & 10 & 1,3 \\
\hline 7. Values children learn & 33 & $\mathbf{4 , 3}$ \\
\hline 8. Curriculum & 39 & $\mathbf{5 , 0}$ \\
\hline 9. Goals & $\mathbf{3 7}$ & $\mathbf{4 , 8}$ \\
\hline 10. Children as an entity & $\mathbf{4 7}$ & $\mathbf{6 , 1}$ \\
\hline $\begin{array}{l}\text { 11. General function of } \\
\text { the Kindergarten }\end{array}$ & $\mathbf{1 0 8}$ & $\mathbf{1 4 , 0}$ \\
\hline Total & $\mathbf{7 7 3}$ & $\mathbf{1 0 0}$ \\
\hline
\end{tabular}

Studying in descending order the views of undergraduate students we found out that the characteristics of ideal Kindergarten are as follow:

1. Space $(\mathbf{3 3}, \mathbf{1 \%})$

2. Kindergarten teacher $(16,7 \%)$

3. General functionof the Kindergarten $(14,0 \%)$

4. Children as an entity $(6,1 \%)$

5. Relations to the wider social environment $(5,6 \%)$

6. Curriculum $(5,0 \%)$

7. Goals $(4,8 \%)$

8. Values children learn $(4,3 \%)$

9. a. Staff $(4,1 \%)$

b. Functional principles $(4,1 \%)$

10. Activities $(\mathbf{2 , 2 \%})$

In the present study the effect of the independent variables was examined trough the analysis of one factor (ANOVA) and no variations occurred. 


\section{Al Macrothink}

International Journal of Learning and Development

ISSN 2164-4063

2016, Vol. 6, No. 3

The first category unit concerns the kindergarten teacher who is the basic element of an ideal kindergarten. This unit gathers the 16,7\% $(N=129)$ of the reports and it is separated in 4 sub categories: training, personality elements, behavior during the educational process and teaching methods.

\subsection{Kindergarten Teacher Training}

The ideal kindergarten should be supported by a Higher University Educational kindergarten teacher, having multisided education and constant awareness of the developments in education, technology and curriculum. The kindergarten teacher should know the preschooler's physiology and of their special features in order to inform parents in case of a problem. In addition is required the knowledge of medicine and biology and their link to entertainment and social education. Furthermore, the knowledge of the basic first aid and of linguistic sufficiency is case of foreign pupils. All these help to holistically approach a child and organize one's teaching.

\subsection{A kindergarten Teacher's Personality}

A kindergarten teacher should be inventive, flexible, responsible, impartial, patient, attentive hard working and loving children.

\subsection{Kindergarten teacher behavior in class}

Kindergarten teacher should be close to children providing the proper time to every pupil, showing respect to their needs, interests and differences. Also, should work individually with every child watching their behavior and reactions while encouraging team spirit and dialogue. Kindergarten teacher should interfere only when asked and help when it is urgent. Furthermore, should accept children's mistakes and promote their autonomy.

\subsection{Teaching methods}

Organizing the teaching program mustn't be based on the teacher's aims only, but thinking about the children's needs, their opinions and interests. Kindergarten teacher should monitor children's interactions before organizing the next activity. She/ he should follow the curriculum but also taking initiative for more activities. Also, she/he should connect the new to the previous knowledge in coherence. It's important to use the alternative "angles", projects and new technology. Her/his basic concern is to entertain children.

The $2^{\text {nd }}$ thematic unit is about the inside and outside space of the kindergarten consisting the major range of reports having $33,1 \%(N=256)$ of the total. This unit is divided in two categories and 4 sub categories. Specifically, the first category "internal space" is divided to: equipment, decoration, functionality, cleanness and finally helping spaces. The second category "external space" is not divided in sub categories.

\subsection{Internal space of a kindergarten}

\subsubsection{The equipment of a kindergarten}

It is essential to have great amount of supervisory material proper for children to use on their 
own. It should be constantly updated to keep both the children and teacher's interest and to provide without change by the responsible entities.

The supervisory material should include audiovisual aids, musical instruments, projectors, DVD players, large TV screens, gym, fitness balls, paperboards, markers, brick toys and a doll house. Children should also play computer games that are both educational and entertaining enough to stimulate them.

\subsubsection{Decoration of a kindergarten}

The walls should be colorful with bright, soft and lively colors. The room should be decorated with children's works like paintings and collages and not with plasticized cards and boards that offer low aesthetics and are tiring.

In the room should be many occasional and permanent corners that are often renewed. Specifically, it is recommended to have a corner of "isolation" that can visit those children who wish to be alone. And an "art" corner with papers to draw and material that can be molded. In this way there will be a calm atmosphere offering children comfort, security and inspiration.

\subsubsection{The functionality of a kindergarten}

The ideal kindergarten should have roomy classrooms where children can move and play in comfort. There should be functional furniture at the same height to the children's so that are easily accessible and offer space and security "economy". There should not be pointed edges or fragile objects but it should be a special floor so that children won't be injured.

The room should be airy and sunny properly formed for the children's needs and activities. Especially practical are the clever spaces of storage. In addition, we should avoid the typical "permanent| corners in which children are bored. On the contrary there should be corners according to the teaching themes that stimulate children.

\subsubsection{Helping spaces of a kindergarten}

Apart from the basic room in which children act, respondents pay attention to the assisting rooms that contribute to the aims of the ideal school. So, there should be a gym, an art and crafts room, a music class, a drama class, a relaxing room and a venue. Also, there should be a library, a physics lab, a greenhouse or a garden. There should also be a dining room, toilets appropriate for the children's age, a laundry and a room for detonations and autonomous creation.

\subsection{External space of a kindergarten}

The kindergarten should be neither centrally located nor isolated. It should be in a quiet area having a big yard with grass or soft material, a garden, a sandpit, a pavilion and protective bars. There should also be facilities such as swings and slides or ropes that enforce their kinetic skills while some flowers could beautify the kindergarten yard. 


\section{MIN Macrothink}

International Journal of Learning and Development

ISSN 2164-4063

The $3^{\text {rd }}$ thematic unit concerns the extra staff of the kindergarten apart from the teachers and consists the $4,1 \%(N=32)$ of the reports. It seems that the extra staff plays a very important role in the smooth function of the school. The staff members can contribute to the complete development of children working complementary with the teacher. This staff should be qualified, experienced and friendly. It could be composed by another kindergarten teacher, a special worker, a psychologist, a P.E instructor, a special education teacher and someone responsible for the cleaning.

The $4^{\text {th }}$ thematic unit is about the activities that take place in an ideal kindergarten indoors and outdoors of it. The percentage of the reports reaches the $22 \%(N=17)$. There are two sub categories; the first is about the indoor activities and the second of the outdoor activities.

\subsection{Outdoor Activities}

This sub category includes activities that can e done in the school playground where children can do exercises, dig, plant, run, jump etc. it is also important to melt the local community (ex. Visit the backers or a museum).

The $5^{\text {th }}$ thematic unit refers to the functional principles of the kindergarten gathering the $4,1 \%(N=32)$ of the reports. Basic element of the proper function is to have enough teachers for the pupils. There should be 7 to 10 children per one kindergarten teacher. More children mean an extra teacher.

The number of the preschoolers is crucial to the schools function. Limited number of children is suggested 12 to 15 .It is extremely important to separate children based on their age (preschoolers- young children) and the ability of parallel teaching in case of a child with learning disabilities.

Concerning the teaching staff there should be two teachers working together in a class. They should be frequently trained and have a good contact between them in order to improve the teaching process and sort out all types of problems. Only one report focuses on the school management mentioning the taking of initiatives about educational matters and obligatory training.

The $6^{\text {th }}$ thematic unit mentions the school relations to the wider social environment reaching $5,6 \%(N=93)$ of the reports. It has two sub categories. First, the connection between the teacher and parents. Second the relation between the kindergarten teacher and the state-community.

\subsection{Relation between kindergarten teacher and parents}

These two parts should be working together on an everyday basis so that any problems can be solved. Parents should participate not only in school events but also in the learning process.In this way the kindergarten will not be just a place to leave one's child when parents are working but they will realize the educational work and any kind of their children's learning difficulties. 


\subsection{Relation between kindergarten teacher and state-community}

Many students think that the connection between kindergarten and the society is vital. The school should go hand with modern society. There is also a reference to the psychological tests that teachers should take before and during the school year. Finally, a participant mentions the hosting of children from other countries, thus showing the perfect relation to society.

The $7^{\text {th }}$ thematic unit is about the principles children learn during their study and has the $4,3 \%(N=33)$ of the reports. Student's views refer to interculturalism, acceptance equality, respect, cooperation, solidarity, justice, responsibility and democracy. In the ideal kindergarten there is no prejudice. On the contrary, the acceptance of diversity is encouraged children from all social classes have the change to study and meet different cultures and languages. In addition, in an ideal school children have the same opportunities. They learn to respect each other's personality, share and play in teams fairly, not to be violent but be responsible for tidying the class.

The $8^{\text {th }}$ thematic unit is about the curriculum and gathers the $5 \%(N=39)$ of the reports. The ideal kindergarten should follow stable schedules with principles and targets accounting to the learning abilities of children. There should also be experiential approaches and actions (like excursions in nature, visits of specialists) and children should play freely or together. The teaching program should be pupil centered team working and creating projects. Projects expand their knowledge, offer many stimulus and enhance interculturalism.Also, children should be involved in interactive and art to improve their talents while physical activities helps their mobility on the other hand they shouldn't be extremely bothered with writing and mathematics.

The $9^{\text {th }}$ thematic unit concerns the goals of the ideal kindergarten, reaching the $4,8 \%(N=37)$ of the reports. There should be a place that corresponds to children needs creating a pleasant and friendly environment. The teachers must provide a secured and comfortable atmosphere without focusing only on educational aims but also promoting interaction.

Furthermore, kindergarten should help children have a smooth transition to elementary school emphasizing on the preschoolers social- emotional development and of many other skills. Skills like autonomy, self-regulation, self-service and communicating with children. This thematic unit is completed with the reference of alternative ways of expression (ex. theatre, paintings, denotations etc.) and not crowding children of lower social class, foreign or bilingual children.

The $10^{\text {th }}$ thematic unit is about dealing with children as an entity reaching the $6,1 \%(N=47)$ of the reports. In the ideal kindergarten children must be the protagonist of the teaching schedule, taking into consideration their interests, their needs and ideas. A student centered model of teaching should be followed, where children have the "main role", act free and daily choose what they want to do during free and organized activities. So that children can improve their skills and build alone their knowledge. 
In addition, a kindergarten is ideal that enables children to learn through creative activities which having fun and expressing their feelings, but having enough time to understand their object better. Also, they should learn to act according to rules, understand basic principles, know their rights and love school. Concerning immigrants' children, it is extremely important to feel secure and familiar in the space.

Concluding the qualitative analysis of the reports, the $11^{\text {th }}$ thematic unit refers to the function of the school, gathering the $14 \%(N=108)$ of the reports. The ideal kindergarten must offer knowledge, care and independence to children giving emphasis to their development features. On the teacher's behalf, they should urge children's participation, providing chances and motives adjusting their teaching. Concerning the place, the participants claimed that the environment should be motivating and thought provoking. Always, teaching rationale (ex. self- acting, socialization) and offer security.

\section{Conclusions}

The educationalists gather all those elements that make them lovable to children and allow children to have a fruitful corporation with them. Via this corporation child live in a respectful environment and help each other while their round development is fully reinforced. In addition, the educationalists are not only present in class to teach and impose rules, but nave a creative part, adjusting to children's needs and helping them efforts. Both parents and teachers regard teacher qualities as the key to good practice, and parents understand that play is an effective means to foster development (Corter\& Pelletier, 1995:6).

Patience towards children understanding their needs caring encouraging and helping them when it is necessary are responded in Garvis, Fluckiger and Twigg (2012) findings. Also, the continuous communication with children, the flexibility in teaching material, the training of teachers completes all the common features that were highlighted. Another element of the educationalist is the avoidance of stereotyped beliefs and racist ideology that allows the active participation of minority children in the educational procedure.

The building hardware, the internal room decoration the extra rooms should be part of the kindergarten. Furthermore, the external spaces are the features of the ideal kindergarten that promotes and sub serves children to feel comfortable, more freely and be expressed in their own way.

The furniture is designed based on the children's height, so that they serve their needs. The walls are painted in the colors children like and create an attractive environment. The individual element of each child is not excluded, but it is displayed on the walls through paintings and handmade crafts. Children have the chance to form on their own the room so it is pleasant according to their needs. It is extremely important to find them in the environment they spend a great part of their daily life and be free to reform it as they are affected through it.

The room of the kindergarten is not confined in the classroom. In cases of full day kindergarten rest hall, dining room and the kitchen are basic elements. There are also expressed ideas of event halls, musical and kinetic actions and a qualitative library. The ideal 
kindergarten has external place with yard that secures children. This is also a parent's ambition a kindergarten to be a place where child feels - and is - safe and engaged in learning (Kagan \&Kauerz, 2006:162). The teacher encourages children to act outside the classroom, in organized and free activities, always having games in the centre of educational procedure.

Parents play a key role in their children's academic progress and school achievement. Parental support of the child in the home (e.g., emotional support, helping with homework, assistance with encouragement, and educational decisions) influence school success (Peterson et al., 2011 in Savas, 2012: 3009). Involvement and participation of parents in schooling has consistently been shown to impact children's improvement and achievement (Epstein, 1983; Fehrmann, Keith, \&Reimers, 1987; Stevenson \& Baker, 1987; Lee \& Green, 2008 in Savas, 2012: 3099).

The basic element of the ideal kindergarten is the relation of it to the families. Family is not excluded from the daily routine of the kindergarten. Families hoped for everyday communication with professionals that allowed them to have a sense of how the day went for their children (Cardona et. al.2012:14). This exchange of information can occur before or after school (Cardona et. al.2012:14). Teacher's main target is to inform and involve parents to the teaching process during the whole school year. The involvement of a mother in daughter's classroom has really helped "It helps me to get to know the kind of kids that she's around and it helps her appreciate her learning abilities and where she's at in her stage so I can kind of compare and contrast what we're doing at home and what she's doing at school" (Cardona et. al. 2012:13).

Both sides ought to help children equally to succeed a smooth passing from the family to the kindergarten environment, supporting any weakness. It would be also beneficial both parents and teachers to examine proposals about better school function and accepting ideas that can offer different viewpoints aiming at the complete development of children. As noticed by a mother "I feel welcomed to sharing my ideas about if I think that something should be changed or if I'm not happy about something or if I want to congratulate them on something that has really been going well'(Cardona et. al. 2012:8).

In addition, the ideal kindergarten sets goals to complete. Not only teaching goals but also goals that allow children to grow their special abilities and skills, to be expressed, participate with interest and work with each other. All these goals help to the physical, social, emotional and cognitive development of children that is the main purpose of the ideal kindergarten. The teacher prepares the educational program and studies the objectives according to the cognitive parts of DEPPS. The goals are simple and clearly stated from the beginning to the end. The kindergarten could not function without the fulfillment of goals that are necessary for the achievement of a structural personality.

Children are the protagonists of the educational process. They choose reform, express themselves freely, and act impulsively. Teacher's needs do not exceed children's needs. In this way the foundations of a complete personality are laid that will be evolved through the passing to the higher educational grades. 
Of course the reference to the values of an ideal kindergarten could not be omitted. The social solidarity, democracy, cooperation, respect, justice, inteculturalism, the equality among the members are principles of vital importance and integral pieces of a kindergarten that aims to supply children with them in order to face the requirements of modern reality.

In general, the ideal kindergarten is a place where children enjoy their stay, they are interested in participating choose freely, accept stimulus, they are urged and they form their character.

\section{Reflection}

The organization and function of an ideal kindergarten is a complex issue. The constant update and serious efforts to solve any problems that interfere to the orderly function and basically taking children into consideration for all activities is the key to create the ideal kindergarten. In this survey the participants were asked to answer only one open content question. In future, it is suggested to investigate student's views of the University of Preschool Educational Department referring to the individual thematic units that resulted from this survey. Also, it would be interesting to research the views of kindergarten teachers and parents as well, about the features of the ideal kindergarten.

\section{References}

Asher, E. The Encyclopedia of Language and Linguistics. Edinburgh: Pergamon Press.

Bardin, L. (1977). L' analyse de contenu. Paris: PUF.

Berelson, B. (1971). Content Analysis in Communication Research. New York: Hafner.

Bruce, T. (2012). Early Childhood Education, 4th Edition. Italy: Hodder Education.

Cardona, B., Jain, S., \& Canfield-Davis, K. (2012, 8 27). Home-School Relationships: A Qualitative Study with Diverse Families. The Qualitative Report, 17 (70), pp. 1-20 http://nsuworks.nova.edu/tqr/vol17/iss35/2

Corter, C., \& Pelletier, J. (1995). Parent Perspectives and Participation in Exemplary Kindergarten Practice. Annual Meeting of the American Educational Research Association, (pp. 2-7). San Francisco .

Dayan, Y., \& Ziv, M. (2012). Children's perspective research in preservice early childhood student education. International Journal of Early Years Education, 20 (3), pp. 280-289 http://dx.doi.org/10.1080/09669760.2012.718114

De Sola Pool, I. (1959). Trends in Content Analysis. Urbana: University of Illinois Press.

Flynn, T. (2006). Development of social, personal and cognitive skills of preschool children in Montessori and traditional preschool programs. Early Child Development and Care, 72 (1), pp. 117-124 http://dx.doi.org/10.1080/0300443910720111

Garvis, S., Fluckiger, B., \& Twigg, D. (2012). Exploring the Beliefs of Commencing Early Childhood Education Graduate Students: Providing Insights to Improve Teacher Education 
Programs. Australian Journal of Teacher Education, 37 (1), pp. 93-105 http://eric.ed.gov/?q=exploring+the+beliefs\&ft=on\&id=EJ969513

Giroux, H. (1994). Slacking off: border youth and postmodern education. Journal of Advanced Composition, 14 (2), pp. 347-366 http://www.jstor.org/stable/20865975

Grawitz, M. (1981). Methods des sciences sociales. Paris: Dalloz.

Henniger, M. (1991). Play revisited: A critical element of the kindergarten curriculum. Early Child Development and Care, 70 (1), pp. 63-71 http://dx.doi.org/10.1080/0300443910700107

Hewett, V. M. (2001). Examining the Reggio Emilia Approach to Early Childhood Education. Early Childhhod Education Journal, 29 (2), pp. 95-100.

Kagan, S., \& Kauerz, K. (2006). Making the Most of Kindergarten. Trends and Policy Issues , pp. 161-170.

Ko, C.-H., \& Chou, M.-J. (2014). Aesthetics in Early Childhood Education: The Combination of Technology Instruments in Children's Music, Visual Arts and Pretend Play. Journal of Social Sciences, 10 (1), pp. 39-45 doi:10.3844/jsssp.2014.39.45.

Lillard, A. (2013). Playful Learning and Montessori Education. American Journal of Play, 5 (2), pp. 157-186.

Lindsay, G. (2015). Reflections in the Mirror of Reggio Emilia's Soul:John Dewey's Foundational Influence on Pedagogy in the Italian Educational Project. Early Childhood Educational Journal, 43 (6), pp. 447-457 DOI 10.1007/s10643-015-0692-7

Miezitis, S. (1971). The montessori method: Some recent research. Early Learning Reviews Of Selected Areas, 2 (2), pp. 41-59 Doi: 10.1007/BF02137791

Moore, D., Cutter-Mackenzie, A., Edwards, S., \& Boyd, W. (2014). Play-Based Learning in Early Childhood. In A. Cutter-Mackenzie, S. Edwards, D. Moore, \& W. Boyd, Young Children's Play and Environmental Education in Early Childhood Education (pp. 9-24). Canada: Springer.

Moscovici, S. (1970). La psychanalyse, son image et son public. Paris: PUF.

Mucchieli, R. (1988). L' analyse de contenu des documents et des communications. Paris: Les Editions ESF.

Myrray, J. (2015). Early childhood pedagogies: spaces for young children to flourish. Early Child Development and Care , pp. 1-18 http://dx.doi.org/10.1080/03004430.2015.1029245

Oppenheim, A. (1992). Questionnaire Design, Interviewing and Attitude Measurment. New York: Continnum International Publishing Group.

Palmquist, M. (1990). The lexicon of the classroom: language and learning in writing classrooms. Carnegie Mellon University.

Saracho, O. (1991). Educational play in early childhood education. Early Child Developent 


\section{Macrothink \\ International Journal of Learning and Development \\ ISSN 2164-4063 2016, Vol. 6, No. 3}

and Care, 66 (1), pp. 45-64 http://dx.doi.org/10.1080/0300443910660105

Savas, A. C. (2012). The Contribution of School-Family Cooperation on Effective Classroom Management in Early Childhood Education. Educational Sciences: Theory \& Practice, pp. 3099-3110.

Sniegoski, S. (1994). Froebel and Early Childhood in America.http://eric.ed.gov/?q=froebel+and+early+childhood+education+in+America\&ft=on \&id=ED385386

Spodek, B. (1981). The kindergarten : a retrospective and contemporary view. Urbana: ERIC Clearinghouse on Elementary and Early Childhood Education.http://files.eric.ed.gov/fulltext/ED206375.pdf

The Reggio Emilia Approach to Early Years Education. (2006). The Reggio Emilia Approach to Early Years Education. Scotland: Learning Teaching Scotland.

Tzuo, P. W. (2007). The Tension between Teacher Control and Children' s Freedom in a Child-centered Classroom: Resolvivg the Practical Dilemma through a Closer Look at the Related Theories. Early Childhood Education Journal, 35 (1), pp. 33-39.

Vamvoukas, M. (2002). Introduction to educational psychology and research methodology. Athens: Grigoris.

Veron, E. (1981). La construction des evenements. Paris: Le Editions de Minuit.

Weber, R. P. (1990). Basic Content Analysis. Newbury Park: Sage.

\section{Copyright Disclaimer}

Copyright for this article is retained by the author(s), with first publication rights granted to the journal.

This is an open-access article distributed under the terms and conditions of the Creative Commons Attribution license (http://creativecommons.org/licenses/by/3.0/). 